\title{
UPAYA PENINGKATAN PENGETAHUAN REMAJA PUTRI MELALUI PEER GROUP DALAM RANGKA PENINGKATAN KONSUMSI TABLET TAMBAH DARAH DI KOTA BENGKULU
}

\author{
Betty Yosephin $\mathrm{S}^{1^{*}}$, Kusdalinah ${ }^{1}$ \\ ${ }^{1}$ Program Studi DIII Gizi Poltekkes Kemenkes Bengkulu
}

*patricknmom@yahoo.co,id

\begin{abstract}
The prevalence of anemia in Indonesia continues to increase from year to year, in 2017 there was a problem at the Kandang Health Center, namely in terms of giving Blood Tablets (TTD) still found $36 \%$ of anemia students with compliance rates of TTD consumption of only $76 \%$, therefore one ways to improve TTD consumption compliance requires education socialization among UKS teachers to increase student knowledge so that it can improve TTD consumption compliance and peer tutors. The methods used in community service are lectures, discussions, and questions and answers and monitoring the development of knowledge transfer from UKS teachers who have received nutrition education to students regarding compliance with TTD consumption. Then the transfer of advanced knowledge from tutors to other school students is done as a form of peer tutors. This community service was carried out in August 2017 until April 2018. The result of this community service activity was an effort to increase compliance with TTD tablet consumption so that no more adolescents or women of childbearing age had anemia and increased knowledge about anemia.
\end{abstract}

Keywords : Knowledge, TTD Consumption, Peer group

\begin{abstract}
ABSTRAK
Pemerintah berupaya menyelesaikan masalah anemia gizi pada remaja putri melalui pendistribusian Tablet Tambah Darah (TTD. Meskipun telah dilakukanl pemberian Tablet Tambah Darah (TTD) di Puskesmas Kandang masih ditemukan siswi anemia sebanyak 36\% dengan tingkat kepatuhan konsumsi TTD hanya 76\%. Oleh karena itu salah satu cara untuk meningkatkan kepatuhan konsumsi TTD diperlukannya sosialisasi edukasi pada guru UKS untuk meningkatkan pengetahuan siswi sehingga dapat meningkatkan kepatuhan konsumsi TTD dan teman tutor sebaya. Metode yang digunakan dalam pengabdian kepada masyarakat ini adalah ceramah, diskusi, dan tanya jawab serta memonitoring perkembangan transfer pengetahuan dari guru UKS yang telah mendapatkan pendidikan gizi kepada siswi mengenai kepatuhan konsumsi TTD. Kemudian dilakukan transfer pengetahuan lanjutan dari siswi tutor ke siswi sekolah lainnya sebagai bentuk tutor sebaya. Pengabdian masyarakat ini telah dilaksanakan pada bulan Agustus 2017 sampai dengan April 2018. Hasil dari kegiatan pengabdian kepada masyarakat ini adalah

44 Edukasi Masyarakat Sehat Sejahtera (EMaSS) : Jurnal Pengabdian kepada Masyarakat Volume 2 No.1 Tahun 2020
\end{abstract}


upaya meningkatkan pengetahuan tentang anemia dan kepatuhan konsumsi tablet TTD sehingga tidak ada lagi remaja yang tidak patuh dalam mengonsumsi TTD.

Kata kunci : Pengetahuan, Konsumsi TTD, Tutor Sebaya

\section{I.PENDAHULUAN}

Peraturan Presiden Republik Indonesia No.42 tahun 2013 tentang gerakan nasional percepatan perbaikan gizi juga seiring dengan pencapaian target dari World Health Assembly atau majelis kesehatan dunia tahun 2025 yang salah satunya adalah menurunkan anemia pada Wanita Usia Subur (WUS) sebesar 50\% (Achadi, 2017). Menurut Riset Kesehatan Dasar tahun 2013, Prevalensi anemia di Indonesia sebesar 21,7\%. Prevalensi anemia pada wanita umur 5-14 tahun sebesar 26,4\% dan umur 15-25 tahun sebesar 18,4\%. Sedangkan prevalensi anemia pada remaja putri di Kota Bengkulu sebesar 43\% (Kemenkes RI, 2013).

Dinas Kesehatan Kota Bengkulu tahun 2016, telah melakukan upaya penurunan anemia pada remaja putri. Data menunjukkan remaja putri mendapatkan tablet tambah darah (TTD) tertinggi yaitu 43,5\% di Puskesmas Anggut Atas dan data terendah dalam pemberian TTD 4,2\% di Puskesmas Kandang (Dinkes Bengkulu, 2016). Konsumsi TTD tersebut masih belum sepenuhnya dipatuhi oleh para siswi untuk mengonsumsinya. Hal ini diperjelas pada penelitian Desita.R (2017) bahwa keputusan minum TTD hanya 74\% dan diketahui siswi yang anemia sebesar 36\% di Sekolah MTSN 02 yang merupakan salah satu sekolah yang berada dalam wilayah kerja Puskesmas Kandang Kota Bengkulu (Desita, 2017).

Anemia pada remaja putri disebabkan oleh faktor kurangnya asupan zat besi melalui makanan, kehilangan zat besi basal, kehilangan darah saat menstruasi, kurangnya pengetahuan mengenai anemia gizi besi dan penyakit infeksi. Darah yang dikeluarkan pada saat menstruasi pada remaja putri rata-rata 16-33,2 cc. sedangkan pada wanita yang lebih tua dan wanita yang defisiensi zat besi jumlah darah saat haid yang dikeluarkan lebih banyak (Wiknjosastro, 2010).

Kegiatan pengabdian kepada masyarakat ini sebagai upaya yang mendorong para siswi untuk meningkatkan konsumsi TTD yang diawali dengan peningkatan pengetahuan mereka melalui guru dan teman sebayanya (peer group). 


\section{METODE}

Sesuai dengan analisis situasi, alternatif pemecahan masalah yang dapat telah dilaksanakan diantaranya :

1. Persiapan

a. Konsolidasi ke pihak Pimpinan UPTD Puskesmas Kandang Mas dan pihak guru-guru UKS di kelurahan Kandang Kota Bengkulu untuk menginformasikan tentang rencana kegiatan pengabdian masyarakat.

b. Konsolidasi dengan pihak sekolah di wilayah kelurahan Kandang Kota Bengkulu terkait data siswi yang akan mengikuti kegiatan edukasi.

2. Pelaksanaan

a. Tahap 1 : memberikan pendidikan gizi kepada 8 orang guru UKS (masing-masing sekolah mewakili 2 orang guru). Guru-guru tersebut mewakili sekolah MTSN 02, MTS Ja-alHaq, MA Jaalhag dan SMAN 11.

b. Tahap 2 : para guru yang telah dilatih mentransfer materi yang telah diperoleh ke siswi. Masing-masing guru memberikan penjelasan kepada 10 siswi di MTSN 02, sehingga pada pengabdian kepada masyarakat untuk Periode Agustus sampai Desember 2017 yang mendapatkan edukasi 8 orang guru ditambah 80 siswi yang berasal dari MTSN 02.

c. Tahap 3 : permintaan 20 orang siswi MTSN 02 sebagai tutor sebaya untuk mengikuti kegiatan pengabdian masyarakat yakni sebagao tutor sebaya di 2 sekolah. Penentuan 20 orang siswi tersebut ditentukan oleh Guru UKS MTSN 02 dengan pertimbangan nilai pretest dan posttest yang baik selain itu siswi mampu berkomunikasi dengan baik.

d. Tahap 4 : sisiwi MTSN 02 sebagai tutor sebaya mentransfer ilmu yang diperoleh kepada siswi sekolah lainnya (MTS Jaa-alHaq, MA Jaal-alHaq dan SMAN 11). Siswi tutor 20 orang memberikan edukasi kepada 90 orang siswi yang berasal dari 3 sekolah tersebut.

\section{HASIL DAN PEMBAHASAN}

Hasil capaian kegiatan terbagi 2 yaitu :

1. Pemahaman yang diberikan kepada guru diharapkan dapat memotivasi siswi untuk menghabiskan TTD, sehingga terjadi peningkatan kepatuhan. 
Pada saat akan dilakukan pemberian materi kepada guru-guru UKS yang mewakili sekolah MTSN 02, MTS Ja-alHaq, MA Jaalhag dan SMAN 11, diawali dan diakhiri dengan pembagian kuesioner tentang pengetahuan mengenai kepatuhan konsumsi TTD, dan diperoleh hasil sebagai berikut :

a. Pre test dan Post test Tingkat Pengetahuan tentang Kepatuhan Konsumsi TTD

Tabel 1. Pre test dan Post test Tingkat Pengetahuan tentang Kepatuhan Konsumsi TTD

\begin{tabular}{llccc}
\hline No & Nama Guru & Pre Score & Post Score & $\begin{array}{c}\text { Peningkatan } \\
\text { Score }\end{array}$ \\
\hline 1 & NL & 80 & 90 & 10 \\
\hline 2 & RH & 70 & 75 & 5 \\
\hline 3 & SE & 60 & 65 & 5 \\
\hline 4 & PW & 70 & 70 & 0 \\
\hline 5 & NW & 70 & 80 & 10 \\
\hline 6 & KP & 55 & 75 & 20 \\
\hline 7 & YS & 80 & 90 & 10 \\
\hline 8 & ST & 70 & 75 & 5 \\
\hline Rata-rata & 69,7 & 77,5 & \\
\hline
\end{tabular}

Berdasarkan tabel 1 hasil pretest dan posttest tingkat pengetahuan guru tentang kepatuhan konsumsi TTD yang memperoleh skor tertinggi adalah guru dengan inisial NL dengan nilai pretest 80 dan posttest 90, namun pada peningkatan skor, guru dengan inisial KP memperoleh peningkatan skor paling tinggi yaitu 20 dengan nilai pretest 55 dan posttest 75 .

Berdasarkan tabel diatas dapat disimpulkan terjadi kenaikan tingkat pengetahuan guru tentang kepatuhan konsumsi TTD, dengan peningkatan skor rata-rata yaitu 8,1. Kemudian 8 ibu guru yang telah mendapatkan edukasi memberikan materi kepada 80 remaja putri di sekolah MTS Negeri 02 Bengkulu.

2. Pemahaman yang diberikan kepada siswi MTSN 02 sebagai tutor sebaya diharapkan mampu menyampaikan materi yang diperoleh kepada siswi sekolah lainnya (MTS Jaa-alHaq, MA JaalalHaq dan SMAN 11) dan meningkatkan pengetahuan yang telah diberi edukasi gizi.

Pada saat akan dilakukan pemberian materi oleh tutor sebaya, diawali dan diakhiri dengan pembagian kuesioner tentang pengetahuan mengenai kepatuhan konsumsi TTD.

a. Pre test dan Post Test Tingkat Pengetahuan tutor sebaya tentang Kepatuhan Konsumsi TTD 
Tabel 2. Skor Rerata Pengetahuan Berdasarkan Hasil Pre Test

\begin{tabular}{lccc}
\hline Sekolah & MTS Jaa-alHaq & MA Jaa-alHaq & SMAN 11 \\
\hline Rerata & 66 & 79 & 75 \\
\hline Maksimum & 93 & 100 & 87 \\
\hline Minimum & 40 & 53 & 47 \\
\hline
\end{tabular}

Berdasarkan tabel 2 hasil pretest rerata tingkat pengetahuan tentang kepatuhan konsumsi TTD didapatkan yang memperoleh nilai rerata tertinggi dari sekolah MA Jaa-alHaq dengan nilai maksimum 100 dan nilai minimum 53, sedangkan skor rerata terendah dari sekolah MTS JaaalHaq dengan nilai maksimum 93 dan nilai minimum 40.

Tabel 3. Skor Rerata Pengetahuan Berdasarkan Hasil Post test

\begin{tabular}{lccc}
\hline Sekolah & MTS Jaa-alHaq & MA Jaa-alHaq & SMAN 11 \\
\hline Rerata & 81 & 90 & 82 \\
\hline Maksimum & 100 & 100 & 100 \\
\hline Minimum & 67 & 73 & 67 \\
\hline
\end{tabular}

Berdasarkan tabel 3 hasil posttest rerata tingkat pengetahuan tentang kepatuhan konsumsi TTD didapatkan nilai rerata tertinggi 90 dari sekolah MA Jaa-alHaq dengan nilai maksimum 100 dan nilai minimum 73, sedangkan skor rerata terendah 81 dari sekolah MTS Jaa-AlHaq dengan nilai maksimum 100 dan nilai minimum 67.

Penyampaian materi dilakukan oleh remaja putri yang telah mendapatkan edukasi deri gurunya, remaja putri tersebut dipilih oleh guru. Para tutor teman sebaya menyampaikan dengan bahasa yang mudah dimengerti oleh temannya. Kegiatan ini dibagi dalam beberapa kelompok kecil remaja putri, tutor menyampaikan materi berisikan manfaat TTD, cara mengonsumsi TTD, dampak yang ditimbulkan anemia. Berdasarkan kedua tabel diatas (tabel 2 dan 3) memperlihatkan kenaikan skor pengetahuan tentang kepatuhan konsumsi TTD dengan peer group, semula rerata tingkat pengetahuan remaja putri di sekolah MTS Jaa-alhaq (66), MA JaaalHaq (79), SMAN 11 (75) menjadi MTS Jaa-alhaq (81), MA Jaa-alHaq (90), SMAN 11 (82). 
Keterlibatan siswi sebagai tutor teman sebaya memiliki dampak positif. Dengan peningkatan pemahaman kepatuhan konsumsi TTD, remaja putri dapat lebih meningkatkan konsumsi TTD 1 butir seminggu atau 4 butir dalam sebulan. Melalui peer group membuat teman sebaya lebih leluasa menanyakan seputar TTD (manfaat TTD, cara mengonsumsi, dampak anemia). Selain itu manfaat lain yang dirasakan oleh tutor teman sebaya ini menjadikan siswi (tutor) semakin paham dan percaya diri untuk memnyampaikan materi ini.

\section{SIMPULAN}

Pemahaman guru MTSN 02, MTS dan MA Ja-alHaq serta SMAN 11 yang berada di wilayah kelurahan Kandang mampu menyapaikan materi kepada sisiwi MTSN 02 dalam upaya meningkatkan kepatuhan mengonsumsi TTD. Hal ini terbukti dari peningkatan skor pretest dan posttest pengetahuan guru.

Adanya peningkatan pengetahuan sisiwi MTS, MA Jaa-alHaq, dan SMAN 11 tentang manfaat dari konsumsi TTD bagi kesehatan setelah adanya penyampaian materi dari siswi tutor dalam bentuk interaksi kelompok bila dilihat perubahan rerata skor pretest dan postest.

\section{UCAPAN TERIMAKASIH}

Tim Pengabdian Kepada Masyarakat mengucapkan terima kasih kepada Direktur dan Kapuslitbang Poltekkes Kemenkes Tasikmalaya, MI Sukasirna Tasikmalaya, dan KPAD Kota Tasikmalaya yang telah membantu kegiatan pengabdian kepada masyarakat berlangsung.

\section{DAFTAR PUSTAKA}

Achadi, Endang. (2017). Peran 1000 HPK dalam Mempersiapkan SDM Indonesia yang berkualitas. Disampaikan dalam Seminar Nasional FKM UNSRI 30 Oktober 2017.

Kemenkes RI. (2013). Riset Kesehatan Dasar; RISKESDAS. Jakarta: Balitbang Kemenkes RI

Dinas Kesehatan Bengkulu. (2016). Data Dinas Kesehatan Kota Bengkulu.

Desita. R. (2017). Hubungan Pengetahuan Gizi, Pola Makan, dan Kepatuhan Konsumsi Tablet Fe dengan Kejadian Anemia pada Remaja Putri di MTSN 02 Kota Bengkulu. Skripsi, Poltekkes Kemenkes Bengkulu.

Wiknjosastro.(2010). Ilmu Kebidanan. Yayasan Bina Pustaka Sarwono Prawirohardjo: Jakarta

49 Edukasi Masyarakat Sehat Sejahtera (EMaSS) : Jurnal Pengabdian kepada Masyarakat Volume 2 No.1 Tahun 2020 